\title{
Functional and environmental impacts of the use of reclaimed asphalt pavement materials and of foamed asphalt
}

\author{
A. Saleh¹, L. Gáspár ${ }^{1,2, *}$ \\ ${ }^{1}$ Széchenyi István University, Department of Transport Infrastructure and \\ Water Resources Engineering \\ Egyetem tér 1., H-9026 Győr, Hungary \\ e-mail: ali.saleh1990@outlook.com \\ ${ }^{2}$ KTI Institute for Transport Sciences Non-Profit Ltd. \\ Than Károly u. 3-5, H-1119 Budapest, Hungary \\ *e-mail: gaspar@kti.hu
}

Submitted: 21/01/2021; Accepted: 25/02/2021; Published online: 11/03/2021

Abstract: Environmental safety related to asphalt mixing plants has been a growing concern due to the high temperature of asphalt mixture production resulting in a lot of energy used and much air pollutants released. Asphalt mixtures with foamed bitumen and RAP can reduce this problem. This paper deals with their functional and environmental effects. In the paper, it was introduced that the hot mix asphalt mixtures bound by foamed bitumen and containing RAP materials provides a good workability, in comparison to "traditional" hot mix asphalt mixtures. However, producing foamed bitumen needs special technological steps before using it as asphalt binder. The use of RAP materials reduces environmental harm and construction costs, besides it preserves the limited resources of stone, sand and gravel.

Keywords: foamed bitumen; RAP; warm asphalt mix; environmental harm; asphalt functional properties

\section{Introduction}

Changes in the environment and its continuous degradation are among the most important problems in the modern world due to extremely dangerous compounds that pollute the environment such as: carbon dioxide $\left(\mathrm{CO}_{2}\right)$ which has a greenhouse effect, carbon monoxide (CO), sulphur dioxide $\left(\mathrm{SO}_{2}\right)$ and nitrogen oxide $\left(\mathrm{NO}_{\mathrm{X}}\right)$, 
which causes excess acidity in the environment [1]. Hot asphalt mixing plants have a large contribution to these emissions because they require heating the asphalt to high temperatures ranging between 140 and $200^{\circ} \mathrm{C}$ to ensure the best coating with aggregates during production HMA, in addition to heating the stones to a high degree [2].

On the other hand, high temperatures require use of much energy and lead to high emissions of dangerous gases $\left(\mathrm{CO}_{2}, \mathrm{SO}_{2}, \mathrm{NOx}\right)$ with dust scattering in the atmosphere (Fig. 1) [3], which threatens the environment and workers' health. In order to mitigate these harmful effects, modern asphalt technology concentrates on the use of eco-friendly technologies [4]. Several techniques were developed that led to a significant decrease in temperature (Fig. 2) and the emission of harmful compounds [5].

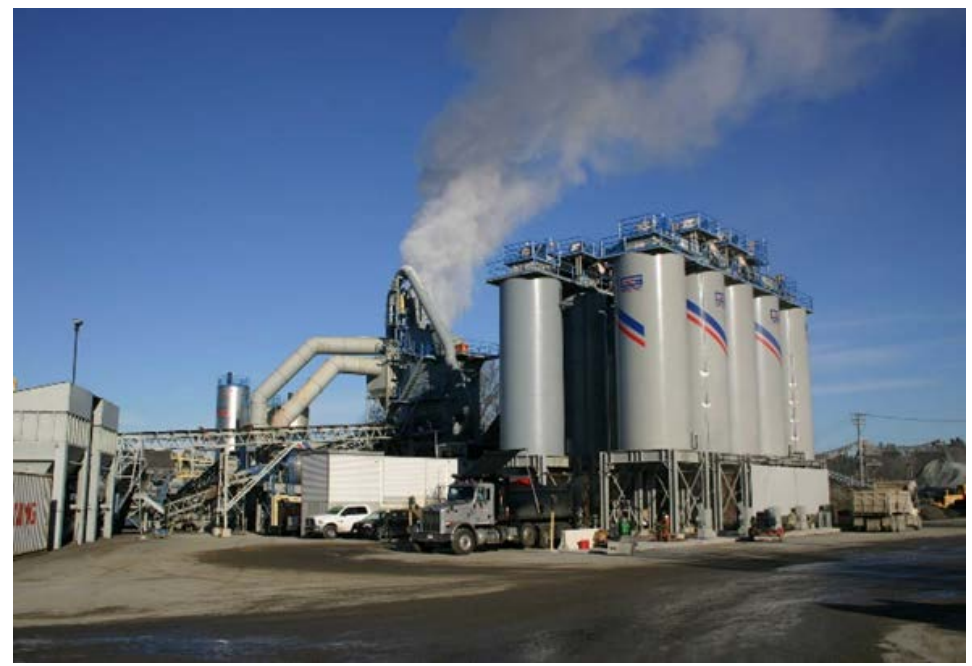

Figure 1. Emissions of mixing plant pollutants [3]

Many countries seek to spend money on new construction methods instead of spending on maintenance and rehabilitation due to the convergence of their costs in a large proportion, so they must find feasible alternatives [6]. Foamed bitumen was found to be the best alternative because of the following reasons:

- In pavements with "unfoamed" bitumen, the damage increases twice when the load is increased by $20 \%$, while in the pavements with foamed bitumen 
binder the damage does not increase more than twice as a consequence of $20 \%$ increase in load [7].

- Foamed bitumen has a higher resistance to fatigue in wet conditions compared to that of bituminous emulsions and mixes [8].

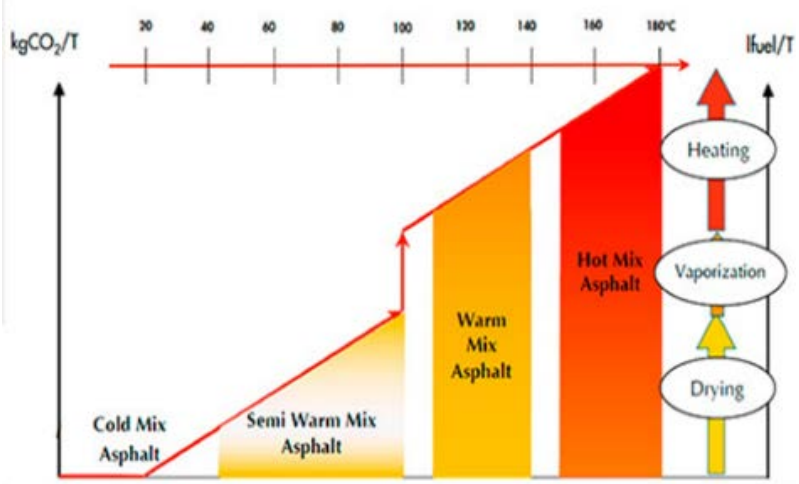

Figure 2. Heating needs of various asphalt mixture types [8]

Foamed bitumen is suitable for pavement repair that has been repeatedly patched; and it can offer a durable solution for pavement sections with large and uncontrollable overloading. There are some other important advantages: increase in granular shear resistance, favourable fatigue resistance, low moisture content compared to bituminous emulsion, good resistance to extreme weather (e.g. heavy rain) effects, fastest way of pavement rehabilitation due to ease of application, speed and compatibility with a wide range of species [9].

\section{Application areas of foamed bitumen}

Foamed bitumen is used mainly as the binder of a warm or a cold asphalt mixture.

\subsection{Warm asphalt mixes}

The development of warm mix asphalt when producing asphalt led to the significant reduction of carbon footprint, coming from its rather low mixing temperature between 100 and $140^{\circ} \mathrm{C}$ [10]. The water is heated above $100^{\circ} \mathrm{C}$ in the hot bitumen so some of it evaporates resulting a mixture of steam, water and bitumen, which is then mixed with the aggregate at low temperature. This foaming 
enables the aggregates to be coated by the bitumen at a lower temperature as shown in Fig. 3 [11].

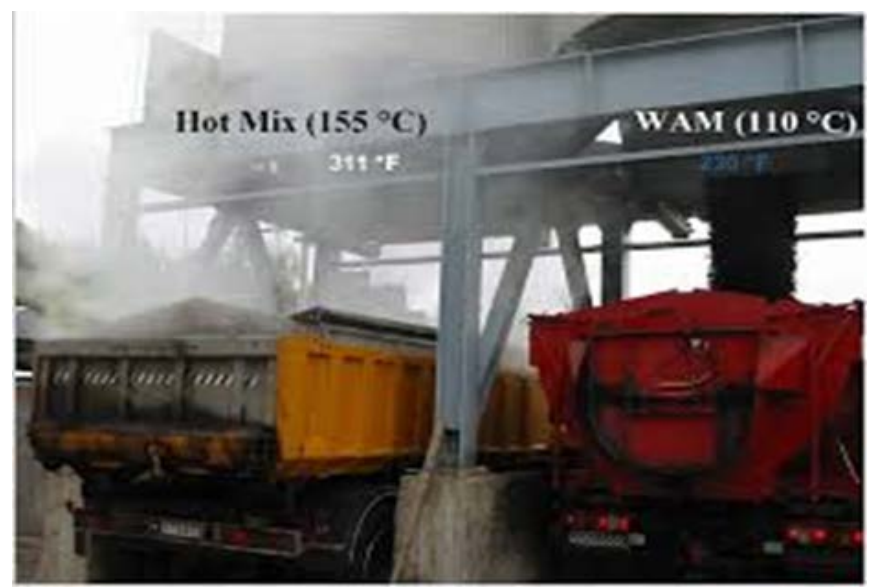

Figure 3. Environmental difference between the production of HMA or WMA [11]

The quantity of water used amounts to $1.2-2.0 \%$ of bitumen weight, which is controlled by a flow meter [10].

The main benefits of producing warm mix asphalt compared to traditional hot one are as follows:

- Lower manufacturing costs

- Less fuel consumption

- Reducing carbon dioxide emissions into the atmosphere

- Reducing harmful vapour and smell in the asphalt mixing plant

- Reducing harmful vapour and smell at the paving site (Fig. 4), thus providing a safer working environment for pavers [12].

- The major advantage of using warm mix asphalts is the significant reduction in emissions, every $11^{\circ} \mathrm{C}$ reduction in mixing temperature halves the emissions entering the atmosphere [13]. It is also an important fact that any HMA production plant can be used to produce WMA, as well [14]. Table 1 presents the production of warm mix asphalt in some selected countries in the period 2013-2019 [15]. 

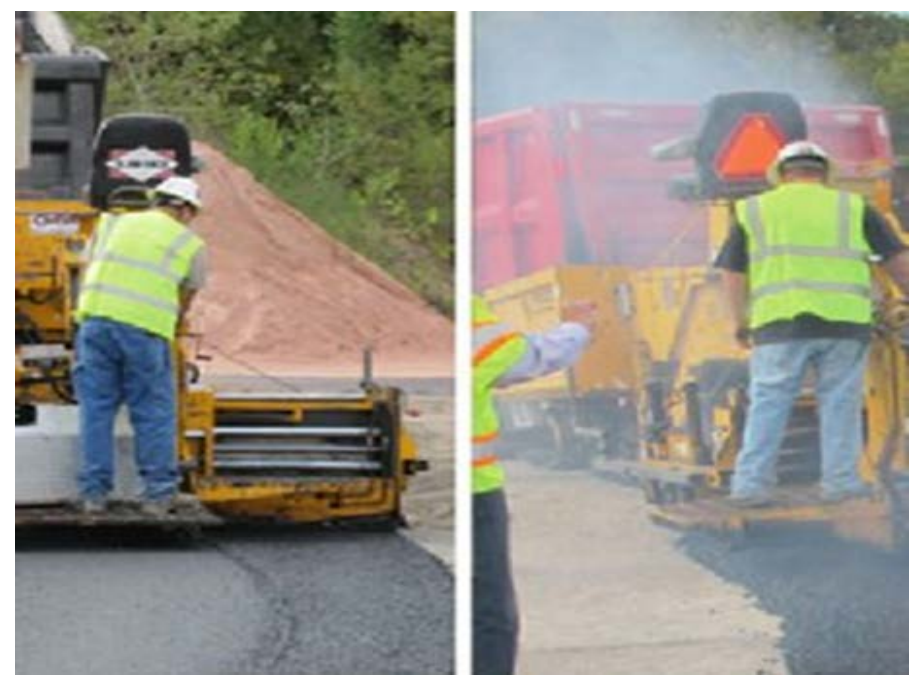

Figure 4. Environmental difference between the laying of HMA and WMA [12]

Table 1. Production of warm mix asphalt in some selected countries in the period 2013-2019 [15]

\begin{tabular}{|c|c|c|c|c|c|}
\hline \multirow{2}{*}{ Country } & \multicolumn{5}{|c|}{$\begin{array}{c}\text { Warm }\left(\mathbf{1 0 0}^{-150^{\circ}} \text { C) asphalt mixture }\right. \\
\text { production (million tons) in year }\end{array}$} \\
\cline { 2 - 6 } & 2013 & 2015 & 2017 & 2018 & 2019 \\
\hline Czech Republic & 0.03 & 0.02 & 0.07 & 0.08 & 0.00 \\
\hline Denmark & 0.12 & 0.20 & 0.34 & 0.33 & 0.32 \\
\hline Finland & 0.00 & 0.24 & 0.43 & 0.31 & 0.20 \\
\hline France & 3.55 & 4.55 & 3.82 & 3.73 & 4.31 \\
\hline Hungary & 0.02 & 0.07 & 0.21 & 0.00 & 0.18 \\
\hline Netherlands & 0.06 & 0.10 & 0.06 & 0.79 & 0.79 \\
\hline Spain & 0.09 & 0.14 & 0.20 & 0.18 & 0.38 \\
\hline USA & 69.00 & 109.00 & 137.00 & 143.00 & 72.00 \\
\hline
\end{tabular}

\subsection{Cold asphalt mixes}

Cold asphalt mixing plants (Fig. 5) are becoming more and more widely used in a lot of countries for producing road base material. 


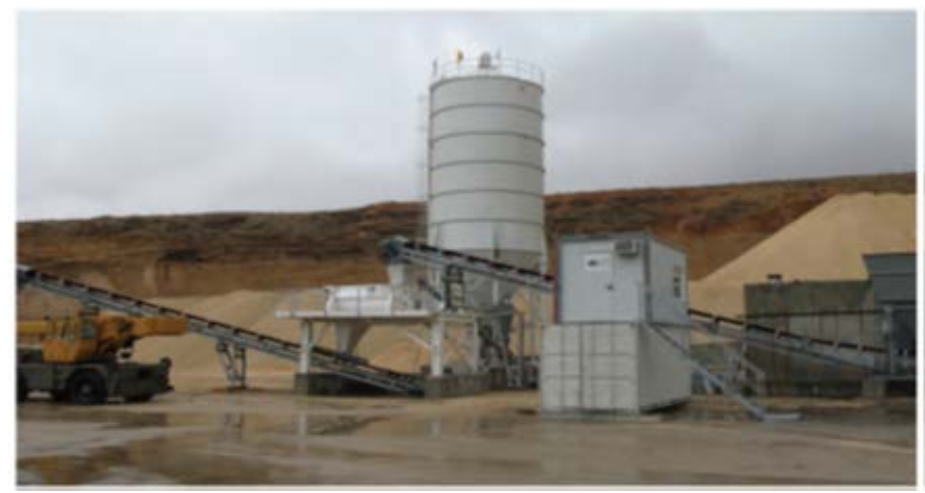

Figure 5. Cold asphalt mixing plant [16]

The initial, operating and maintenance costs of this kind of plant are low, because there is no heating or dust collection; so the unit cost of cold asphalt mix is much below that of HMA. However, it is an important requirement that pre-graded, single size aggregates must be used for the production of high quality cold asphalt material [16].

As a binder of cold mix asphalt mixtures produced in these kinds of plants either foamed bitumen or bituminous emulsion is used,

The benefits of cold mix plants are as follows [17]:

- Low initial cost of equipment

- Low maintenance and operating costs

- Low unit cost of cold asphalt mixture produced

- Minimizing the environmental impact since no aggregate heating and drying are needed

- $\quad$ Ease of achieving high capabilities

- No waste materials

- RAP can be also used.

Table 2 presents the production of cold mix asphalt in some selected countries in the period 2011-2019 [15]. 
Table 2. Production of cold mix asphalt in some selected countries in the period 2011-2019[15]

\begin{tabular}{|c|c|c|c|c|c|}
\hline \multirow{2}{*}{ Country } & \multicolumn{5}{|c|}{$\begin{array}{c}\text { Cold (below } \mathbf{5 0}^{\circ} \mathbf{C} \text { ), asphalt mixture production } \\
\text { (thousand tons) in the year }\end{array}$} \\
\cline { 2 - 6 } & 2011 & 2013 & 2015 & 2017 & 2019 \\
\hline $\begin{array}{c}\text { Czech } \\
\text { Republic }\end{array}$ & 9.9 & 9.6 & 5.4 & 4.0 & 6.0 \\
\hline France & $1,600.0$ & $1,550.0$ & $1,808.0$ & $1,977.0$ & $1,672.0$ \\
\hline Hungary & 40.0 & 58.8 & 60.0 & 50.0 & 60.0 \\
\hline Slovakia & 3.0 & 0.0 & 1.0 & 1.0 & 3.0 \\
\hline Spain & 200.0 & 86.7 & 94.0 & 80.0 & 110.0 \\
\hline Turkey & $1,020.0$ & $1,050.0$ & 783.0 & $1,048.0$ & 905.0 \\
\hline
\end{tabular}

\section{Usages RAP material}

When using cold and warm bitumen mixtures, there is a possibility not only to reduce the energy needed but also less new aggregate is necessary if RAP materials are applied in a "conventional" or a foamed bitumen asphalt mixture. The following asphalt mixing plant types could be suitable for the use of reclaimed asphalt pavement material.

\subsection{Drum mix plant}

In a drum mix plant, $15-20 \%$ of RAP can be added by an enforcement mounted around the rotating cylinder at the start of the mixing zone. Diameters of RAP grain sizes should be less than $30 \mathrm{~mm}$. It is fed into a hopper that is a ramp through a variable speed feeder, and onto a RAP conveyor belt [18].

The new aggregates are heated in the drying and heating section, then the RAP is mixed with the new aggregates, the filler and the bitumen are in the mixing section [19]. The percentage of RAP is limited due to the production of fumes or blue smoke when the RAP is mixed with the superheated new aggregates.

\subsection{Counter flow drum mix plants}

In a counter flow drum mix plant, max. 60\% RAP materials with diameters not exceeding $30 \mathrm{~mm}$ can be used. The reclaimed material is fed into the rotating drum through a collar wrapped around the drum, then the aggregate is heated to a high temperature to allow heat transfer to the RAP, and removing any moisture present in the RAP, then the combined mixture is heated. RAP fumes are extracted by a fan [20]. 
Table 3 presents the total quantity and application shares of RAP materials in some European countries in 2019 [15].

Table 3. The total quantities and application shares of RAP materials in some European countries in 2019 [15]

\begin{tabular}{|c|c|c|c|c|}
\hline \multirow[t]{2}{*}{ Country } & \multirow[b]{2}{*}{$\begin{array}{c}\text { All } \\
\text { available } \\
\text { RAP } \\
\text { (million } \\
\text { tons) }\end{array}$} & \multicolumn{3}{|c|}{ \% of RAP used in } \\
\hline & & $\begin{array}{c}\text { hot } \\
\text { and } \\
\text { warm } \\
\text { asphalt }\end{array}$ & $\begin{array}{c}\text { on-site } \\
\text { cold } \\
\text { asphalt }\end{array}$ & $\begin{array}{c}\text { plant } \\
\text { cold } \\
\text { asphalt }\end{array}$ \\
\hline Belgium & 1.64 & 79 & 0 & 0 \\
\hline Croatia & 0.21 & 35 & 2.5 & no data \\
\hline $\begin{array}{c}\text { Czech } \\
\text { Republic }\end{array}$ & 2.80 & 14 & 25 & 0 \\
\hline Finland & 1.50 & 100 & 0 & 0 \\
\hline Germany & 13.40 & 82 & 0 & 0 \\
\hline Hungary & 0.15 & 98 & 1 & 1 \\
\hline Norway & 1.17 & 28 & 0 & 1 \\
\hline Romania & 0.61 & 0 & 5 & 0 \\
\hline Slovakia & 0.16 & 40 & 48 & 0 \\
\hline Slovenia & 0.15 & 23 & 10 & 0 \\
\hline Spain & 1.49 & 0.1 & 1 & 6 \\
\hline
\end{tabular}

\section{Laboratory tests on RAP materials and foamed bitumen}

A laboratory test series was carried out to determine the influence of various RAPcontent and the use of foamed bitumen binder on the Marshall-stability value of asphalt mixtures [21]. Some of the test results will be presented.

\subsection{Aggregates}

In the test series, five mixture types with different RAP materials percentage in aggregate were used, as follows:

- $\quad$ Type (A) - 100\% new aggregate.

- $\quad$ Type (B) - 75\% new aggregate $+25 \%$ RAP.

- $\quad$ Type (C) - 50\% new aggregate $+50 \%$ RAP. 
- $\quad$ Type (D) - 25\% new aggregate + 75\% RAP .

- $\quad$ Type (E) - 100\% RAP.

All of the aggregate variants had been pre-calibrated according to standard test methods for particle size distribution as shown in Fig. 6, before they were used to produce "conventional" HMA mixtures and foamed bitumen mixtures.

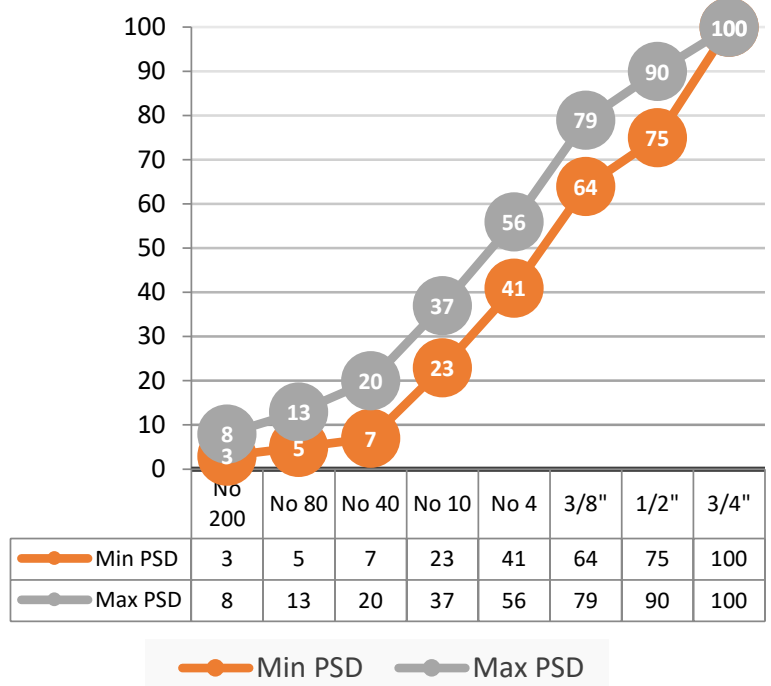

Figure 6. Gradation limits for checking aggregate variants [21]

\subsection{Bituminous binder}

The bitumen used as binder in producing HMA and foam bitumen asphalt mixtures had the characteristics are shown in Table 4.

Table 4. Characteristics of test bitumen

\begin{tabular}{|c|c|c|}
\hline Laboratory test & Before loss of heating test & After loss of heating test \\
\hline Penetration (0.1 $\mathbf{~ m m})$ & 66 & 51 \\
\hline Softening point $\left({ }^{\circ} \mathbf{C}\right)$ & 49 & 53 \\
\hline Ductility (cm) & 153 & 112 \\
\hline Loss of heating (\%) & 0.2 & 0.2 \\
\hline
\end{tabular}




\subsection{1.“Conventional” hot mix asphalt (HMA) mixtures}

The HMA mixtures were produced using $5 \%$ by weight bitumen as binder. The specimens for stability measurement were made by Marshall-method, in a cylindrical mold with a diameter of 4 inches (about 100mm) and a height of 2.5 inches (about 63mm) -. The samples were stacked inside the mold with a hammer weighing 10 pounds (about $4.5 \mathrm{~kg}$ ) freely falling from a height of 18 inches (about $450 \mathrm{~mm}$ ), where the sample is stacked on both sides by 75 blows.

Fig. 7 presents the Marshall-stability (an important performance prediction measure) results, while Fig. 8 shows the VFb (voids filled with bitumen) results of the 5 HMA variants listed in point 4.1.

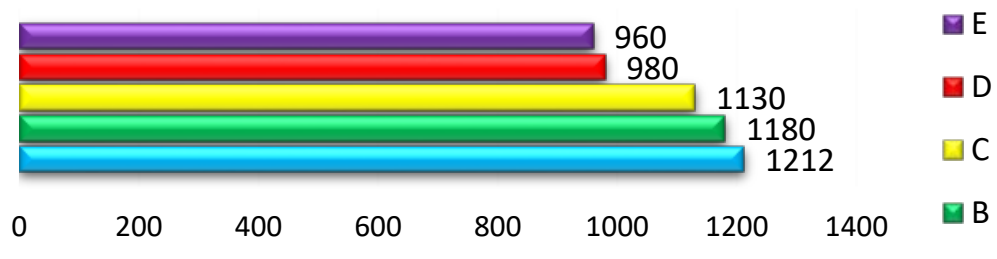

Figure 7. Marshall-stability results $(\mathrm{kg})$ of 5 HMA variants

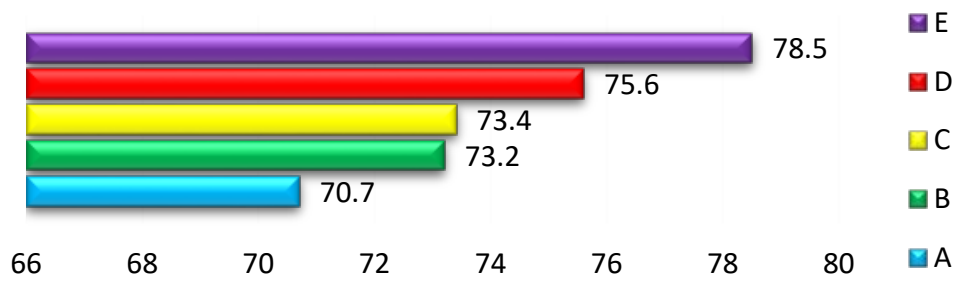

Figure 8. VFb (voids filled with bitumen) results (vol\%) of 5 HMA variants

4.2.2. Foamed bitumen bound asphalt mixtures

The foamed bitumen bound asphalt mixtures were produced using $2.5 \%$ by weight foamed bitumen as binder. 
Fig. 9 presents the Marshall-stability results of the 5 foamed bitumen asphalt variants listed in point 4.1.

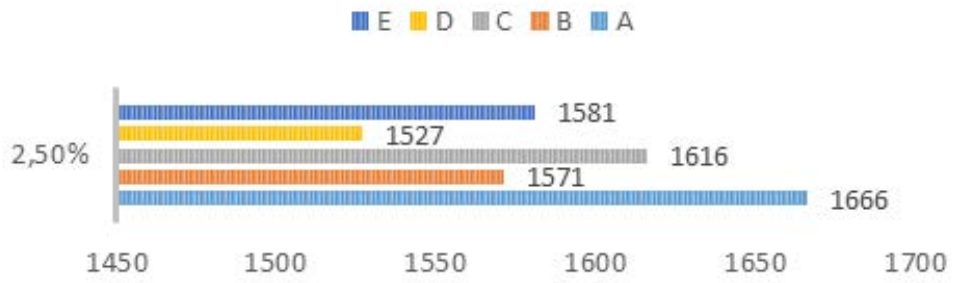

Figure 9. Marshall-stability $(\mathrm{kg})$ results of 5 foamed bitumen asphalt variants

\section{Discussion}

Fig. 10 shows that the chosen gradation limits were away from the restricted zone [22], thus, the dust proportion values would not effect on the mixture. Several studies state that the restricted zone has a considerable negative effect on the rutting performance of asphalt mixtures [23].

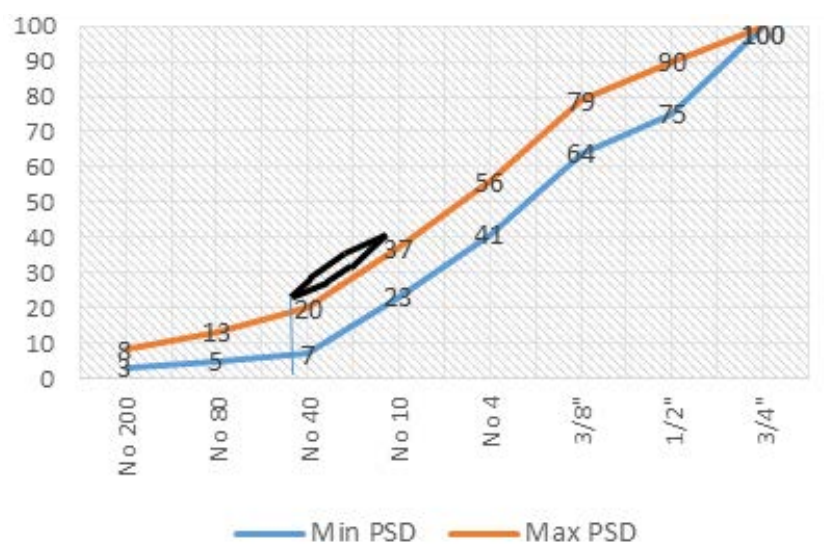

Figure 10. Gradation outside the restricted zone

Fig. 7 shows that the Marshall-stability values decrease with increasing RAP materials share, because the residual bitumen in the reclaimed asphalt pavement increases the Marshall-flow value in the mixture resulting lower cohesion, thus 
dissociation takes place in the asphalt mixture reducing its stability. Fig. 8 illustrates that voids filled with bitumen are increased with higher RAP-share. This tendency can be explained by the residual bitumen in the reclaimed asphalt pavement that increases the quantity of bitumen in the mixture. Consequently, the total asphalt binder would be unable to hold aggregate in place - segregation of the mix during construction could occur - resulting in too low in-place density.

Fig. 11 presents that the Marshall-stability values are considerably increased due to fact that the asphalt mixture is made at lower temperatures, so the residual bitumen in the RAP increases the hardness of the asphalt mixture. In addition to it, the aggregate grains covered with bitumen provide a suitable surface for sticking to the foam at ambient temperature resulting a rather stable mixture. It can be quantified in the relatively high Marshall-stability values measured.

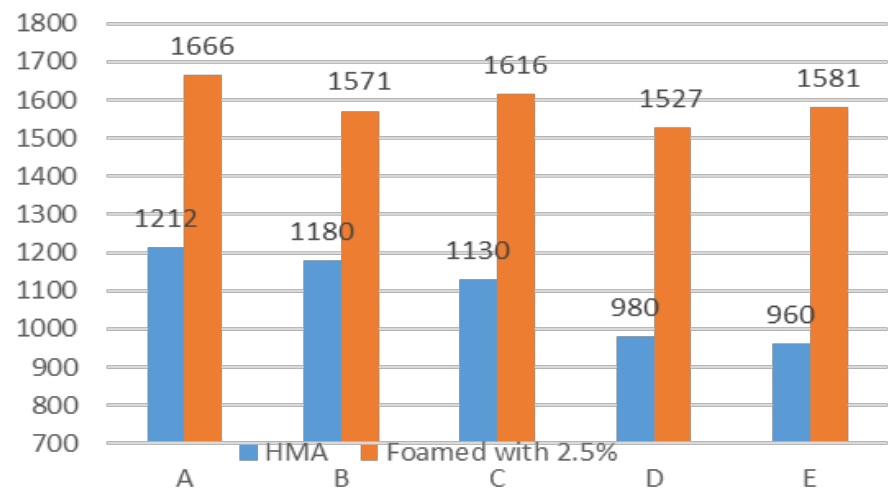

Figure 11. Comparison of the Marshall-stability values of HMA and foamed asphalt mixture 


\section{Concluding remarks}

Environmental safety related to asphalt mixing plants has been a growing concern due to the high temperature of asphalt mixture production resulting in a lot of energy used and much air pollutants released. That is why many research works have been concentrated on the reduction of asphalt mixing temperature by using warm, half-warm and cold mixtures all over the world. One of the most successful relevant research directions is the application of foamed bitumen as a binder of asphalt mixture, besides an important environment-friendly research area is the use of RAP (reclaimed asphalt pavement materials) in new asphalt mixtures.

In this paper, it was introduced that the hot mix asphalt mixtures bound by foamed bitumen and containing RAP materials provides a good workability, in comparison to "conventional" hot mix asphalt mixtures. However, producing foamed bitumen needs special technological steps before using it as asphalt binder. Nevertheless, the use of RAP materials in a new asphalt mixture has several economic-ecological advantages, among others, reduction in the construction costs; much lower greenhouse gas emissions by eliminating the significant fuel consumption required to acquire and process raw materials for "virgin" mix; preservation of the limited resources of stone, sand and gravel; ensuring at least as high quality as the "conventional" asphalt mixture has. The results of a laboratory test series showed in the point 4 of present paper prove that adding RAP materials in a growing proportion increases the Marshall-stability value (an important performance prediction measure) of the mixture. The continuation of the research work mentioned would concentrate on the development of a performance optimizing mathematical model for the clarification of the relationship between the variables of bitumen foaming process.

\section{References}

[1] N. Hunter, A. Self, J. Read, The Shell Bitumen Handbook. Sixth Edition, Shell International Petroleum Company Ltd., (2015) 762 p.

[2] W. Barthel, J. P. Marchand, M. Von Devivere, Warm asphalt mixes by adding a synthetic zeolite, Proceedings of the 3rd Eurasphalt and Eurobitume Congress, Vienna, May 2004, (1) (2004) pp 1241-1249.

[3] J. D'Angelo, E. Harm et al., Warm-mix asphalt: European practice. Federal Highway Administration, Washington, DC, Technical Report FHWA-PL-08007, (2008) 72 p. 
[4] V. Garcia, N. Fann et al., Assessing the Public Health Impact of RegionalScale Air Quality Regulations, EM: Air and Waste Management Association's Magazine for Environmental Managers. Air \& Waste Management Association, Pittsburgh, PA, (2008) pp. 25-30.

[5] D. Newcomb, An Introduction to Warm Mix Asphalt, National Asphalt Pavement Association, Lanham, MD, (2010) 7 p.

[6] A. Almeida-Costa, A. Benta, Economic and environmental im-pact study of warm mix asphalt compared to hot mix asphalt, Journal of Cleaner Production (112) (4) (2016) pp. 2308-2317.

[7] A. Sharma and B. K. Lee, "Energy savings and reduction of $\mathrm{CO}_{2}$ emission using $\mathrm{Ca}(\mathrm{OH})_{2}$ incorporated zeolite as an add-itive for warm and hot mix asphalt production,” Energy (136) (2017) pp. 142-150.

doi: ht tps ://doi.org/10.1016/j . energy.2016.03.085

[8] K. Kuna, G. Airey, N. Thom, Mix design considerations of foamed bitumen mixtures with reclaimed asphalt pavement material, International Journal. of Pavement Engineering (18) (10) (2017) pp. 902-915.

doi: https ://doi.org/10.1080/10298436.2015.1126271

[9] R. Chandra, A. Veeraragavan, J. M. Krishnan, Evaluation of Mix Design Methods for Reclaimed Asphalt Pavement Mixes with Foamed Bitumen, Procedia - Social Behavioral Sciences (104) (2013) pp. 2-11.

[10] M. del Carmen Rubio, F. Moreno et al., Comparative ana-lysis of emissions from the manufacture and use of hot and half-warm mix asphalt," Journal of Cleaner Production (41) (2013) pp. 1-6.

[11] J. C. Nicholls, H. K. Bailey et al., Specification for Low Tem-perature Asphalt Mixtures, TRL Published Project Report PPR666 (2013) 74 p.

[12] L. You, Z. You et al., Assessment of nanoparticles disper-sion in asphalt during bubble escaping and bursting: Nano hydrated lime modified foamed asphalt, Construction and Building Materials (184) (2018) pp. 391-399. doi: https ://doi .org/10.1016/j . conbuildmat . 2018.06.234

[13] S. Hauguel, Presentation to the Irish Branch of IAT, Edinburgh, UK ( 2013) $14 \mathrm{p}$. 
[14] R. Mohd Hasan, Z. You et al,.Characterizations of foamed asphalt binders prepared using combinations of physical and chemical foaming agents," Construction and. Building Materials (204) (2019) pp. 94-104. doi: https ://doi .org/10.1016/j . conbuildmat . 2019.01.156 .

[15] D. B. Sánchez, G. Airey et al., Effect of foaming technique and mixing temperature on the rheological characteristics of fine RAP-foamed bitumen mixtures, Road Materials and Pavement Design 21 (8) (2020) pp. 21432159.

[16] H. D. Lee, Y. Kim, Validation of mix design procedure for Cold In-Place Recycling with foamed asphalt, 4th Interna-tional Conference on Maintenance, Rehabilitation of Pave-ments and Technological Control MAIREPAV 2005, (2005) pp. 1000-1010. doi: https://doi.org/10.1061/(asce) 0899 1561(2007)19:11(1000).

[17] C. W. Schwartz, S. Khosravifar, Design and evaluation of foamed asphalt base materials, University of Maryland, Col-lege Park, MD, Technical Report MD-13-SP909B4E, (2013) 86 p.

[18] H. Shao, L. Sun et al., A novel double-drum mixing technique for plant hot mix asphalt recycling with high reclaimed as-phalt pavement content and rejuvenator, Construction and Building Materials (134) (2017) pp. 236-244.

[19] K. L. Pan, J. F. Gao, et al., The more important role of archaea than bacteria in nitrification of wastewater treatment plants in cold season despite their numerical relationships, Water Research (145) (2018) pp. 552-561.

[20] M. Zaumanis, M. C. Cavalli, L. D. Poulikakos, Effect of rejuvenator addition location in plant on mechanical and chemical properties of RAP binder, International Journal of Pavement Engineering (21) (4) (2020) pp. 507-515. doi: https ://doi .org/10.1080/10298436.2018.1492133.

[21] A. Saleh, The possibility of design the asphalt mixture using foamed asphalt, Tishreen Universit. Journal. - Engineering Sciences Series (41) (3) (2019) URL http://journal.tishreen.edu.sy/index.php/engscnc/article/ view/8779.

[22] J. Zhang, L. A. Cooley Jr. et al., Effect of Superpave defined restricted zone 
on hot-mix asphalt performance, Trans-portation Research Record (1891) (1) (2004) pp. 103-111.

[23] C. T. Weston, A study into the mechanical properties of foamed bituminous stabilised materials, MSc Thesis, Cape Peninsula University of Technology, Peninsula Technikon, (2001) 139 p. 